\title{
External Interventions and State Fragility, Failure and Collapse: Comparative Analysis of African Experiences
}

\author{
Embiale Beyene \\ Department of political science and international studies, Bahir Dar University, Ethiopia
}

\begin{abstract}
States fragility, failure and collapse are the results of both domestic and external determinant factors. This article provides a critique of the debates of failing states, failed states, and collapsed states in Africa by examining three cases: DRC, Burundi, and Somalia. It tries to highlight the impacts of external interventions on functionality, viability and sovereignty of African states. It presents the various interventions and their impacts on state viability in Africa. It argued that by taking similar paths of intervention with the same logic of the past, it is difficult to solve problems related to state failures in Africa. Instead, there has to be a different path of the statebuilding process that takes into account Africa's realities and the interest of the majority, not the interests of the elites and the donors. Besides, instead of focusing on the idea of the liberal peace theory of republicanism, cosmopolitanism, and a free-market economy, it is better to address state-society relations in Africa. Hence, Africa should import those devices and institutions that advance its interests. Moreover, it should be clear that the problems and their impacts are trans-boundary that need transnational cooperative and integrative responses. The rebuilding of a failed state and preventing sates from failure through both curative and preventive approaches have to be the concerns of the 21 st-century global governance, peace, and security narratives.

Keywords: State, State Building, Securitization, Peace Operations, Burundi, Democratic- Republic- of- CongoDRC, Somalia
\end{abstract}

DOI: $10.7176 / \mathrm{IAGS} / 88-02$

Publication date: November $30^{\text {th }} 2020$

\section{Introduction}

A state is considered as a sovereign if it has sovereign control over a given territory, holds a monopoly on the legitimate use of coercive physical force within its borders, mobilizes masses for requests of the state, collects taxes, and protects lives, properties, and freedoms of its nationals from internal and external threat (Cem, 2009). It is related to Machiavelli's and Max Weber's understanding of the state. It is a political and legal institution with the ultimate source of law for itself and has proper territorial and governmental legitimacy.

Failed or collapsed states contrasted with the ideal of the Westphalian state systems that exercise full sovereign powers over territory and population, has a functioning government that monopolizes legitimate violence and provides public goods, and can make and keep international obligations (Yoo, 2011). When this monopoly on the use of coercive force eroded, it begins to lose its control over its people and territory; and its ability to collect taxes and render the services (Cem, 2009; Eriksen, 2011). According to Machiavellian/Weberian understanding, state failure occurs when the national government loses the monopoly of the means of violence.

The term "failing," "failed," or "collapsed" is unsettled, but they have been used to portray cases of severe political crises in specific countries like Burundi, DR Congo, and Somalia. Most scholars agree that they have some common attributes like loss of physical control over territory and people, lack of a monopoly on the use of force, declining legitimacy, an inability to provide services to its people, and a lack of capacity to implement policies or promote economic development and run international obligations (Usman, and Hany, 2007).

\section{Conceptual Debates}

The debates on state failure and collapse gathered momentum and have become part of the global governance and security discourse since the early-1990s (Usman, and Hany, 2007). Compared to the earlier periods, the state breakdown that emerged during the 1990s became more rampant and destructive with human, national, and international security implications and strategic concerns (Yumlu, 2012; Fukuyama, 2005; Baker, 2007). The end of the Cold War and September 11, 2001, terrorist attacks are two important episodes held as responsible for the recent recognition and interest in matters relating to state weakness (Olowu, and Paulos, 2016). Since September 9/11, the discourse of securitization shifted from a "big power" lens to a "small power" lens (Baker, 2007). Despite the existential security and governance threat debate, there is an argument in the literature that rejects the idea of failed states as a politicized, ethnocentric, hegemonic concept with interventionist connotations (Newman, 2009; Ashraf and Clare, 2008). Hence, the sharing of the disease debate is problematic.

There is a glaring gap between the de-jure sovereignty that the international system affords such states and their de-facto capabilities to serve their populations and act as responsible members of the international community. The failed state debate emerged as a result of the apparent discrepancy between negative (nominal) 
and positive (real) sovereignty- the sovereignty game (Newman, 2009). Collapsed, failed, and fragile are range of concepts that have emerged to describe states that do not live up to the Weberian expectations of what states should deliver and how states should work (Olowu, and Paulos, 2016). They indicated post-Westphalian world where notions of inviolable and equal state sovereignty and autonomy eroded; where there are both state and non state actors; where insecurity and conflict is primarily characterized by civil war, insurgency and state failure; and where solidarity norms and responses related to governance and human rights are transcending absolute norms of sovereignty and non-interference (Newman, 2009).

The functional abnormality of the state could be understood as a process in which the state fails to discharge its responsibility due to a steadily declining of capacity. Based on their performance states are classified as strong, weak, failing, failed or collapsed (Eriksen, 2011). Gross also identified five types of dysfunctional states: anarchic states without central government like Somalia; phantom or mirage states with semblance authority like DRC; anaemic sates weakened by insurgent groups; captured sates dominated by elites; and aborted states which failed before they were ever consolidated (Jean-Germaine, 1996). Some understand them as "disrupted states" to refer to states that are unconsolidated at the periphery and are often in an ongoing state of entropy (Usman and Hany, 2007). Some still see them as a low-income country in which economic policies, institutions and governance are so poor that development is highly unlikely (Usman and Hany, 2007).

\subsection{Fragile States}

State fragility is difficult to define partly because the term itself is fluid and partly because it represents a continuum, with the possibility of a state moving in and out of fragility, depending on its ability to respond to internal and external shocks (Ncube, and Basil 2013). Fragility is essentially a dynamic process where states may not always display signs and elements of fragility; may be more obvious at some times than at others. Development partners have tried to categorize fragile countries using different performance indicators or indexes.

Fragility refers to the inability to deliver basic services to their nationals in a complete manner either because of weak capacity, weak institutions and poor policies, political instability, lack of will or a combination of all these factors (Usman and Hany, 2007; Ncube, and Basil 2013). They do not have a legitimate monopoly on the use of force, and a country's territories is not completely controlled by the central government and have little ability to provide services (Cem, 2009; Tusalem, 2016). Furthermore, fragility is a matter of degree - ranging from states that have ceased to have capability and function but name and cannot provide security or welfare to anyone, to certain states that can deliver basic services to most of their citizens (Cem, 2009; Tusalem, 2016).

In some cases a state may possess some of the features of statehood, but not in others. It may have a monopoly over the means of violence, but unable to provide infrastructure, or maintain the rule of law or it may have a functioning military, but an inefficient bureaucracy (Eriksen, 2011). They are characterized by various aspects of state deficits in terms of political commitment, willingness, legitimacy and stability; institutional, technical and administrative capacity; functional authority; economic performance; good governance; human security, prudent financial management; state structures; peace and provision of public goods (Olowu, and Paulos, 2016).

The foremost signs of state fragility are lack of willingness and capacity or state ineffectiveness and political violence. The former related with enforcing contracts, protecting property, providing public goods and raising revenues and the latter refers to the existence of repression or civil conflict. The general essence of fragility is that states are not performing all responsibilities in equal footing and effectiveness. They perform well in some areas and fail in others. Fragility is when there is a partial provision of core functions of the state. Hence, a state is fragile if state institutions cannot or will not deliver core functions to the majority of its nationals in uniform and constant manner.

\subsection{Failed States}

Despite there is no agreement on the definition of state failure, generally, they are unable to carry out their purpose of existence (Jean-Germaine, 1996). Some define a failed state as has no effective control over its territory; unable to uphold its monopoly of violence; and lack of legitimacy and efficiency (Cem, 2009; Tusalem, 2016; Eriksen, 2011; Rotberg, 2004). Zartman (1995) also developed the idea of state failure along the lines of Hobbesian social contract theory that focuses on the relationship between the state and citizen. For Zartman, state failure occurs when they are unable to perform their respective functions. According to Rotberg (2002: 85), "nation-states fail because they can no longer deliver positive political goods to their people. Their governments lose legitimacy, and in the eyes and hearts of a growing plurality of its citizens, the nation-state itself becomes illegitimate".

A failed state is a state that can no longer perform its basic security, peace, governance, and development functions. According to Rotberg (2003:5), "Failed states are tense, deeply conflicted, dangerous, and contested bitterly by warring factions." Failed states lose their control of territory and people due to political and criminal violence, two or more insurgencies, varieties of civil unrest, not able to achieve economic growth or 
development, massive economic inequities, and violent competition for resources (Rotberg, 2003). Here it is a state in name only where its government is unable to maintain public services, institutions, or authority and that central control over territory does not exist but de jure (Newman, 2009). The civil wars that characterize failed states usually have roots in ethnic, religious, linguistic, or other inter-communal enmities (Rotberg, 2004).

In such states, democratic debate is noticeably absent, and legitimacy is in doubt. Only the institution of the executive functions and the legislature, bureaucracy, judiciary, and the military have lost their sense of professional responsibility and exist solely to carry out the orders of the executive and to oppress citizens and are often highly politicized institutions (Rotberg, 2004). According to Potter (2004), indicators such as the restrictions on the free flow of information, the subjugation of women, the inability to accept responsibility for individual or collective failure, the extended family or clan as the basic unit of social organization, the domination by a restrictive religion, the low valuation of education, and the low prestige assigned to work are main attributes of such states (cited in Orman, 2016).

Corruption flourishes on a destructive scale, inflation and smuggling become rife, and terror can breed along with the prevailing anarchy that undermines real national and per capita levels of annual GDP (Rotberg, 2004). Physical infrastructure decays and living standards decline rapidly, lose legitimacy among their citizens, and suffer internal armed conflict, often rooted in longstanding ethnic, religious, or regional rivalries (Yoo, 2011). In failed states, non-state actors control resources and population; the government cannot monopolize legitimate violence or provide public goods, and the economy has usually collapsed, producing famine, refugee flows, and human rights disasters (Yoo, 2011).

Other symptoms of state failure include the erosion of authority to make collective decisions, and inability to provide reasonable public services, and the loss of capacity to interact informal relations with other states, revolutionary wars, genocides, and politicides, and adverse or disruptive regime transitions (Iqbal, and Harvey, 2008). The Fund for Peace (2006) uses a list of 12 indicators to evaluate state stability; these indicators include demographic pressures, refugees and displaced persons, group grievance, human flight, uneven development, economic decline, the delegitimization of state, public services, human rights, security apparatus, factionalized elites, and external intervention (Iqbal, and Harvey, 2008).

Fragile states lack regime legitimacy, the capacity to respond to service delivery, territorial presence and control, and responsibility. Security and social amenities are felt, at best, in the capital city, leaving the large part of the country unprotected and ungoverned. Lack of control over the army, coupled with the influx of small arms makes a state less able to contain uprisings. No sound economic policies existed, leadership was authoritarian and patrimonial, and democratic space was dwindling, opposition parties targeted, the media gagged, and politics of exclusion practiced (Ncube, and Basil 2013). Economic mismanagement, inept economic policies, weak governance, low levels of economic development, and weak economic basis, historical patterns of exclusive economic growth (Ncube, and Basil 2013).

State failure is different from a weak state where the latter is about the diminishing performance, while the former is about the malfunction of one or more of the state functions. State failure is relational and relative that refers to a state's performance relative to others (Usman and Hany, 2007). Most failed states are in Africa, in particular post-conflict states, such as Burundi, the Democratic Republic of Congo, Liberia, Sierra Leone, and Sudan (Tusalem, 2016). A failed state is different from collapsed states in the sense that a failed state has a minimal bureaucracy that imperfectly delivers public goods; provide security and mediate conflicts on an ad hoc or informal basis, and partial delivery of social services (Heilbrunn, 2006). In a collapsed state, however, citizens have no channels to mediate conflicts, public services are unavailable, and in the worst cases, they are subject to random violence, warlords and militia contest, and administrative, economic, political, and social organizations fragment into smaller units (Heilbrunn, 2006). A failed state collapses when its bureaucracy ceases to function, public services are unavailable, and violence becomes commonplace.

\subsection{Collapsed States}

State collapse is not a onetime incident but rather a long term poor performance of the state. According to Zartman(1996:pp) a state has collapsed 'when the basic functions of the state are no longer performed'. These states are characterized by lack of functioninal state institutions; breakdown of governmental and societal structures; breakdown of good governance, law and order; lose of power, legitimacy, symbol of identity and societal cohesion and can no longer assure security (Usman and Hany, 2007; Zartman, 1996;Eriksen, 2011).

It refers to central state institutions and authorities that ceased to function. It is a rare and extreme version of the failed state where political goods obtained through private or ad hoc means- Somalia being the only clear case of it (Rotberg, 2004). A collapsed state exhibits a vacuum of authority, a mere geographical expression, a black hole into which a failed polity has fallen, and there is no state but a stateless society (Ibid.2004). Here the rule of the strong is common (Rotberg, 2003). In such contexts, states have no significant capacities to perform their core services to its inhabitants. In general, the terms describe a situation in which a central government has either lost presence in a significant portion of real estate (territorial collapse) or has lost the capacity to rule a 
territory in which it has a physical presence, or both (Menkhaus, 2003). A collapsed state refers to a situation in which the structure, authority, law, and political order have disintegrated and where its institutions can no longer exercise authority over its political and economic territory (Solomon, and Cornelia, 2004).

Generally, there are three basic approaches to conceptualize state failing, failure, and collapse: the political and legal; the historical and developmental; and the sociological perspectives (Thürer, 1999). Failed States are essentially associated with internal and endogenous problems and featured by the internal collapse of law and order; the absence of bodies capable of representing the State at the international level and being independent of the influences of the outside world. In accordance with a political and legal perspective, Rogue States, Weak States, Non-States, Phantom/Mirage States, Anemic States, Captured States, and the Aborted States have referred to either legal or political weaknesses which have cross-border negative effects upon the international system.

The historical and developmental perspective claims that existing failed States have been affected by three geopolitical factors: during and after the Cold War, where the two superpowers supported regimes in power and denying it at the end; the heritage of colonial states and regimes formation which destroy traditional political and social structures; general processes of modernization which encouraged social and geographical mobility but were not counterbalanced by nation-building processes capable of placing the State on a firm foundation (Thürer,1999).

According to the sociological perspective, the problem of the failed state is characterized by two contexts. The first is the collapse of the central government that claims the monopoly of the legitimate use of physical force within a given territory'. In such monopole States, the police, judiciary, and other bodies serving to maintain law and order have either ceased to exist or are no longer able to operate. The second is the brutality and intensity of the violence used. Finally, the Monopole States and the Anarchic States are considered in the Sociological Approach as they stress the collapse of the core government in the context of the Weberian definition of statehood (Thürer, 1999). In a nutshell, state fragility is about the variation in performance, state failure is about the inability to deliver what is expected from state or the existence of a nominal state, and state collapse is the absence of the state with its institutions or the existence of stateless societies.

\section{The Debate on the Causes of State Failure or Collapse}

There is no general agreement among scholars as to which principal factors that lead to state breakdown: economic, or political, or social factors (Heilbrunn, 2006). Most analysts accept the multi-causal, multidimensional, and mutually reinforcing nature of the drivers of failure, and place different importance on certain causal factors (Ncube, and Basil 2013). The factors that contribute to states' collapse are both inside-out and outside-in processes involved both internal and external factors (Yumlu, 2012). Failing states are the results of a legacy of unresolved historical inequities, including colonial rule, the role of the superpowers during the Cold War, the role of international financial institutions in a structural adjustment program, poverty, corrupt elites, xenophobia, parochial political culture (Baker, 2007).

There are agential, structural, and synthetic casual explanations of state failure (Townshend, 2007). The agential causes attributed to the actions of individuals and groups in terms of greed and fear, poor and oppressive leadership, corruption, neopatrimonialism and clientelism, predation, and warlord politics. While, the structural components depict underdeveloped economic, social, and political structures; bad political culture; poor statesociety relations; arbitrary borders; underdeveloped governance institutions; systemic exclusion from global capitalism as the causes of state failure. The synthetic approach tries to merge both the agent and structural casual factors for state collapse (Townshend, 2007).

The major primary drivers of conflict and fragility in Africa include lack of good governance; economic and social exclusion; economic collapse and worsening poverty; state weakness and collapse; religious extremism; and ideological exclusion (Ncube, and Basil 2013). Natural resource curse; the proliferation of small arms and light weapons; superpower rivalry; youth bulge, and demographic stresses are also secondary drivers for state breakdown in Africa. Tertiary drivers are related to the neighborhood, regional, and international Effects (Ncube, and Basil 2013).

Global factors such as slave trade, colonialism, cold-war, structural adjustment programs, international trade, migration flows, economic interdependencies, and global economic shifts all have impacted the viability of states. The legacies of colonialism were also critical to understand state failure discourse. Colonial administrations left deeply flawed states by selectively including some groups while excluding others from the political arena (Heilbrunn, 2006). Africa's post-independence rulers inherited artificial states that are created by European colonial powers at the Berlin conference of 1885 (Hentz, 2004). Hence, they are imported states which did not organically evolve from Africa's reality but driven by the interests of European colonizers.

During the Cold War, the two superpowers and their allies interfered in the affairs of African states, supporting factions with funding, military aid, troops perceived critical for the interests of the former at the expense of the latter. The super-powers supported any client state that is strategically significant to meet the 
interests of the big boys of the time. This situation hides the real undemocratic features of African states. However, when the cold war was over, and the big boys deny their support, African states' disclosed their actual behaviors (Hentz, 2004). After the war, African countries become "Cold War Orphans," that are devoid of their internal capacity and super-power support (Ncube, and Basil 2013; Brooks, 2005).

One of the external causes of state failure was the structural adjustment programs of international financial institutions in the 1980s and 1990s in Africa. After the Cold War, the World Bank and IMF initiated a whole series of interventions to promote good governance through structural adjustment, economic liberalization, and privatization that aimed at pushing back the predominance and power of state structures and pave the way for civil society engagement. The state capacity and state-building agenda were not given nearly as much thought or emphasis as the state downsizing agenda and pave the way for neo-patrimonial and predatory regimes in Africa (Fukuyama, 2005). In the absence of strong domestic demand, demand for institutions was generated externally by various conditions attached to the structural adjustment program, project lending external aid agencies, and the direct exercise of political power in failed, collapsed, or occupied states (Fukuyama, 2005).

External actors consider state failure in Africa both as moral devastation and as a security peril. In line with this, these actors have a dogmatic assumption and wishful thinking that all states shall follow a model of Western liberal democracy (Hagmann, and Markus, 2009). The Rostow modernization model intervention, where one fits for all and as if there are similar paths and ways to build/rebuild states in Africa. In terms of ideology, it is the same as the ideology of colonialism- the civilization mission. The external interventions fail to recognize the different principles and culture that politics and governance in many African countries operate (Moe, 2010). Besides, the interventions created gaps between declared objectives and de facto commitment and capacity, lack of local-level representation and ownership, and the re-enforcing alliance between the west bloodsuckers and African elite dictators. This alignment between the external actors and the political elites marginalized the governed and affected state-society relations in Africa (Moe, 2010).

The State failure debate of the west did not take into thought the Atlantic slave trade, Colonial and neoColonial experiences of Africa that created permanent contradictions and crises in the continent (E. Akani, 2016). Endogamous factors such as civil war, ethnic identity, or authoritarian rule are given precedence over exogamous factors such as the international political economy, external interferences, and various transnational forces. Thereby, the implicit but wrong institutional breakdown of the African state resulted in a breakdown within African societies themselves (Hagmann, and Markus, 2009). Hence, both internal and external factors need to be considered to better unearth and understand the reality of state collapse in Africa.

\section{Impacts of Failed / Collapsed States}

State failure creates numerous challenges for humans, national, regional, and international peace, security, and governance. Problems associated with failing states like terrorism, civil wars, poverty, and violations of human rights threaten peace and security on both regional and global levels. Under contexts of state failure and collapse, it is difficult to ensure security, peace, and development that also present a challenge for global governance from different angles (Baker, 2007). Consequently, poverty, disease, violence, and refugee flows accompanying state failures strain humanitarian costs (Brooks, 2005).

The domestic effects of state failure and collapse are severe challenges for the citizens' day to day activities and life. State collapse is especially devastating, as the total disintegration of law and order creates anarchy and its resultant insecurity and gross violations of nationals' liberty and rights. Generally, it shifts the attention from development to warmonger (Baker, 2007). When there is a gross violation of human rights and freedoms of nationals, the international community has a moral and legal responsibility to protect civilians under the doctrine of the "Responsibility to Protect," which was endorsed by the United Nations in New York in September 2005.

State failure and collapse also have strong regional and neighborhood effects. The civil war that often accompanies state failure and collapse can easily spill over into neighboring countries through refugee and insurgent movement and support (Cojanu, and A. I., 2007). State failure has also negative effects on economic growth in bordering countries by creating additional investment for accommodating refugees, and to protect the spread of malaria and other diseases (Chauvet and Collier, 2005; Cojanu, and A. I., 2007). Some argue that states neighboring a failed state are also likely to experience subsequently higher levels of political instability, unrest, civil war, and interstate conflict. There is also a likelihood of state failure itself diffusing to other states (Iqbal, and Harvey 2008).

At the global level, these states allow drug production and trafficking, international terrorism, the proliferation of crime: breeding grounds for extremism, save heaven for organized terrorist and criminal groups, flourishing violence, and illicit economic activity (Brooks, 2005). Failed states also pose legal challenges where societies cannot enter into or abide by treaties; cannot participate in the increasingly dense network of international trade, environmental, or human rights agreements and institutions; cannot enforce contracts between their citizens and foreigners or protect settled property interests (Brooks, 2005).

So it is mandatory to understand the trans-boundary nature of the problem and work cooperatively across 
levels (Cojanu, and A. I., 2007). As lawlessness spreads and corrupt non-state actors seize control over various parts of the country, failing states become ideal incubators for a variety of threats of international scope. The trafficking of women and children in the DRC, refugee flows from Sudan, the spread of AIDS and malaria throughout weak states in Africa, the illegal flow of conflict diamonds from countries such as Liberia and the Republic of Congo, and supporting militias and insurgencies in neighboring states are the critical challenges presented by failed states in Africa.

Despite great differences in approach, the reports, analyses, experts, committees, and think-tanks seem to agree on one point: a solution to problems like international terrorism, failing states, civil wars, poverty, and human rights violations calls for an integrated approach to security. Its principle is that peace, security, political and economic development, and respect for human rights are inextricably linked. It is argued that economic breakdown and political instability are serious consequences arising from state failure and collapse than the security dangers posed to the external environment. In short, the negative domestic impacts are by far greater than its external impacts.

\section{The Debate on Responses to State Failure or Collapse}

Both internal and external pressures account for state reconstruction. Without carefully considering local situations thinking and doing state-building and other proposed solutions from outside does not work (Heilbrunn, 2006). The majority of policies in international conferences largely reflect donors' interests. As a result, local people tend to see state-building assistance as illegitimate and refuse to accept it. Although international actors have advocated the importance of ownership, grassroots representation, or participation in the decision-making process has generally become a ritual devoid of substance. Focusing only on political order may not make sense. Hence incorporating the social order is essential (Brooks, 2005; Yoo, 2011). To have a viable and functional state, liberal democracy, and liberal economic system requires better scrutiny of the ontology on the ground.

In response to state failure, international, regional, and sub-regional actors and institutions, and states, have taken steps to address the immediate humanitarian and security problems through means that range from food aid to the deployment of peacekeeping forces (Brooks, 2005). The international community has sought to reverse state failure by fostering diverse political parties, strengthening constitutional and legal norms relating to good governance, building an independent and effective judiciary, reconstituting a professional military and police service, and holding free and fair elections (Brooks, 2005).

However, the current international responses to failed states are often counterproductive. These measures are haphazard, fragmented, and short-term responses that sometimes exacerbate the problem instead of downing it. Some of the limitations of international responses to state failure are little understanding of the problem; insufficient awareness of the role of the international community; the solutions applied tend to be one size fits all; and there is no understanding of shared responsibility to use bottom-up and top-down approaches to solve the troubles (Ashraf and Clare, 2008). Global stability will lie in the creation of aware citizens who can see paths of state-building and participate, and trust in their institutions (Ashraf and Clare, 2008). The state failure responsive measures should take into account both domestic and external factors attributed to state collapse (Hentz, 2004).

The global governance institutions, security organizations, and developmental institutions recognize that an effective state is a necessary condition for solving peace, security, governance, and development related problems. Generally, there is a consensus that only sovereign states that perform the functions that make them sovereign will allow human progress to continue (Ashraf and Clare, 2008).

In the state-building processes, it is critical to devise ways to empower and participate citizens in every decision-making as a continuous process of deepening and broadening the rights and obligations of citizenship (Ashraf and Clare, 2008). The development of institutions through the creation of governance capacities is among the mechanisms of sovereign rehabilitations (Fukuyama, 2005). State-building is about the external attempt to build or reinforce institutions (Zartman, 1995). Contrary to the concept of state formation, which is mainly an endogenously driven mechanism, state-building encompasses a variety of exogenous strategies (e.g., military occupation, peacekeeping, national reconstruction, foreign aid) aimed to develop governance. The statebuilding is a dynamic, citizen-oriented mechanism that is necessary for the constitution of a legitimate economic, social, and political order (Ashraf and Clare, 2008). As long as the problem of African statehood is a capacityproblem, there will be no suitable solution to resolve the statehood crisis than handling the capacity crisis. Because international peace and security depend on the existence of independent states capable of controlling their territories, policing their populations, and discharging their international obligations (Yoo, 2011). Hence, addressing both capacity and autonomy is essential.

Contrary to the arguments against external interventions in the name of addressing state failure, there are recommendations to encourage interventions by removing obstacles found in international law and policy (Yoo, 2011). According to Yoo(2011), though there is a lack of direct benefit to the intervening state, intervention does not discard state sovereignty, but it may require accepting adjustments to the borders of failed states. International law, therefore, should encourage, rather than discourage, intervention. International law could 
further advance this process by allowing for different forms of governance within territories and by permitting the alteration of pre-existing borders (Yoo, 2011). Since 1991, various efforts have been made to restore state failure, but the international interventions failed to pacify and reinforce or create an institution of government.

\section{Comparative Assessment of Cases in Africa}

In a period of about 80 years of colonial rule, Africa was divided into a number of artificial states with sole preferences and whims of the colonialists and little regard for the desires of the inhabitants of Africa (Thomson, 2010). African states all share a post-colonial status. Stemming from this shared post-colonial history is the 'artificial nature' of Africa's state borders and the notion that statehood was imposed on African societies (Solomon, and Cornelia, 2004). A pattern of centralization and monopolization of power by new ruling elites is also characteristic of African states inherited from colonial administrations. African states are tormented by a pervasive external context and continuous dependency. Consequently, Africa is the least developed continent in the world that suffers from the highest levels of human insecurity, deprivation, and poverty (Ibid.2004).

The problem is very serious in Africa. African states have occupied a prominent place in the discussion about state failure, collapse, and reconstruction. Consequently, they are perceived to be threatened by 'collapse', 'failure', 'fragility', and 'weakness' as they degenerate into nightmarish 'shadow', 'quasi' or 'warlord' states (Hagmann, and Markus, 2009). Democratic Republic of Congo (DRC), Liberia, Sierra Leone, and Sudan are failed states and Somalia is a collapsed state in Africa (Rotberg, 2004). Moreover, it is because of external recognition that many of Africa's weak states continued to exist (Eriksen, 2011). The sources of disorder in Africa are varied and include colonial legacy, the Cold War, and state failure (Bates, 2005).

\subsection{State Fragility in Burundi}

State fragility in Burundi has been both a cause and consequence of political instability (Nkurunziza, 2018). The root cause of state fragility traced back to the divide and rule policies of colonialism that were inherited by postcolonial elites. Therefore, state fragility in Burundi is first and foremost the result of the strategies and policies of its colonial masters and corrupted political leaders, who are motivated by personal interests (Ibid). State fragility in Burundi displays all five dimensions that generally characterize fragility: groups came to power through coups d'états or constitutional fraud, lack of effective steering a development process, neglected and underdeveloped private sector, insecurity and civil wars, and vulnerable to political and economic shocks(Ibid).

Burundi has a long history of violence and oppression, much of it linked to the politicization of ethnicity. The context resulted in over a decade of civil war between 1993 and 2003 that involved multiple armed groups organized along with Hutu versus Tutsi lines (Wilén, \& Paul D., 2018). At the same time, post-colonial Burundi had a long tradition of strong resistance to foreign involvement in its domestic sphere that made external interventions a difficult task to manage the conflict. Moreover, international efforts to resolve the ongoing ethnic strife have been challenged by leaders' zeal to stay in power, coup attempts, and mistrusts among various fractions. However, there were interventions from its neighbours, AU (AMIB 2003), USA, UK, and UN (operation in Burundi 2004) to handle the problem (Ibid.2018).

It is one of the poorest countries in the world and lags behind many human development indicators. In addition to being poor, Burundi is highly vulnerable to shocks. Since independence, it is in a multidimensional fragility trap that has considerably limited its economic development and progress that improve the living standards of the population. The most well-known aspect of this fragility is the high degree of political instability and violence that are endemic to the country. Political fragility has hampered efforts to strengthen economic resilience by preventing the development of a modern private sector and perpetuating reliance on foreign aid. More recently, years of political and economic fragility, combined with a growing population leading to a third important aspect of fragility: environmental fragility.

The mix of persisting political instability, growing factional violence, and the deteriorating macroeconomic situation has hit the living standards of the population hard. In post-independent Burundi, political volatility in leadership, ethnic violence, ethnic polarization, and the violation of ethnic minority rights are features of its politics. Since the early days of independence, Burundians have mainly accessed and controlled political power through violence. Since independence, the country has changed leadership 11 times - six of these through military coups.

Underpinning Burundi's political fragility is weak governance and institutions. The incomplete process of building their capacity is among the elements of its fragility trap. Decades of civil war have considerably limited the extent to which civilian institutions developed. The prevalent of patronage and less emphasis on the need for meritocratic criteria undermine civil institution building in it. In turn, poor governance negatively affects the ability of the state to provide security for citizens, deliver social services, manage public investments, or encourage agricultural and other private sector growth. Corruption, abuses of the judicial system, lack of security and access to the judicial system, and criminality are all main challenges of the country. According to international indicators, Burundi is one of the countries with the worst governance records in the world as of 


\section{4.}

Colonial legacies, the post-independence assassination of the freely elected president, ethnic polarization, and sparking waves of revenge ethnic violence undermined democratic governance in Burundi. However, in the pre-colonial period, such ethnic hostility and loyalty were not pronounced, where the king was serving regardless of ethnic and clan-based lineages.

The instability in Burundi can be seen from various historical origins or angles. The first is the colonial administration that weakened the pre-colonial governance and created a sense of rivalry among social groups by introducing divide and rule policies. Before colonialism, it was a very strong, centralized, and stable state in the sub-region, with power controlled by a secular monarchy whose authority was generally uncontested throughout the country (Nkurunziza, 2018). The colonial masters undermined the traditional system of governance by introducing "divide and conquer" policies that broke the secular identity of the people of Burundi and introduced ethnic balkanization that weakened the traditional state structure in it.

While the Belgian colonial authority is attributed to the creation of state fragility in Burundi, Burundian political elites, particularly those within the Tutsi group who ruled the country for most of the post-colonial period, perpetuated it through their leadership (Ibid. 2018). The military dictatorship is the dominant part of postcolonial Burundi's history. In addition to colonialism, the role of political elites, political volatility, the weakness of both $\mathrm{AU}$ and $\mathrm{UN}$ peacekeeping operations are crucial to understanding the fragile nature of the state. According to the Fund for Peace (2019) annual report, Burundi is the fifteenth with a 98.2 score.

\subsection{State Failure in Democratic Republic of Congo}

Before colonialism, there was no political entity with the boundaries of the modern state of Zaire (1960- 1997) and the Democratic Republic of Congo (DRC) since 1997. Several different ethnic groups lived within the area today comprise the DRC (Gourou, 2000). These groups lived in small kingdoms and republics that had protected their citizens for centuries (Davidson, 1992).

After getting its independence in 1960, in the early 1970s DRC was emerging as a relatively strong authoritarian one-party state with centralized power of the "arch-dictator" (Townshend, 2007). Mobutu developed a patrimonial regime that used the military to control both the country's mineral wealth and to control the separatist pressures. He also used the classic divide and rule techniques among various ethnic groups during his time (Hentz, 2004). As rich as Zaire was in mineral resources, Mobutu depended on external assistance, in particular from the U.S., to maintain his patronage network.

The end of the Cold War was the beginning of his demise where the level of bilateral aid declined, and the International Monetary Fund and World Bank were no longer as willing to engage in the debt relief with Mobutu (Hentz, 2004). In the post-cold-war era, the DRC lost its strategic significance to the West owing to the later shift to a greater interest in human rights. As both the armed forces and the state depended on foreign aid for survival, these dramatic reductions signaled the final stages towards failure. Also, regional insecurity fuelled by providing refuge and support to insurgent groups in neighboring Angola and Uganda pushed the latter to act to remove leaders from power. In this way, both global and regional systemic pressures converged to facilitate the sub-state accumulation of coercive power (Hentz, 2004).

DRC experienced various military coups, civil wars, assassinations, erosion of legitimacy, internal displacement of people, social problems, poverty, foreign intervention (Hentz, 2004). Highly-personalized, neopatrimonial, corrupted, and centralized authoritarian rule which seeks to monopolize political control by establishing various networks with unlimited embezzlement for personal gain (Rotberg, 2004). Furthermore, the economic downturn in the global economy, foreign debt problem, private predation, mismanagement, and escalating inflations were also challenges that exacerbate state failure (Ibid).

When all the relevant data is analyzed, the Democratic Republic of Congo is a failed state (Cem, 2009). Firstly, the country is unable to exercise sovereign control over its borders, and secondly, it cannot provide the services of protection of the lives, rights, and property of its citizens (Ibid). Furthermore, it has no political stability, and the state cannot exercise its sovereignty fully over its borders, the ruling regime again cannot provide health services, and the country is unable or unwilling to control child trafficking. In DRC patrimonial and predatory rule depends on a patronage-based system of extraction from ordinary citizens (Fukuyama, 2005; Rotberg, 2004). The people of the D.R.C. denied the opportunity to choose or change their government through democratic and peaceful means. Hence, they do not have a recognizable government with legitimate authority sanctioned by the population of the state (Solomon, and Cornelia, 2004).

Since independence, the government of D.R.C is both undemocratic and weak in terms of its authority and influence (Ibid.2004). Since then, the country is characterized by cross-border raids, the interference of neighbouring states in its domestic affairs, and serious human rights abuses (Solomon, and Cornelia, 2004). Judging from the discussion of the nature and performance of the state, it is apparent that DRC does not qualify as a functional state, especially in its record for political freedom and civil liberty, as well as its provision of political and social goods. Despite being seriously impaired in certain realms of statehood, this state has not 
reached the point of complete collapse and can thus not classified as a collapsed state (Ibid. 2004).

The wars in the DRC have multiple causes revolving around four clusters of factors: economic factors, institutional factors, regional factors, and global geopolitical factors. These factors are interrelated and cannot be treated in isolation in understanding the causes of the conflicts or in the design of strategies for overcoming conflicts and for post-conflict economic development. The overall weak state of the economy played a key role in the genesis of the conflicts (United Nations, 2015).

Institutions have played a critical role in the genesis and perpetuation of conflicts in the DRC. The institutions established under the colonial regime and in the post-independ-ence era generated and perpetuated antagonisms around the control of the state and national resources while sowing the seeds for inter-regional and inter-ethnic conflicts. The disputes around the configuration of the federalism vs. centralized - which characterized the political discourse during the struggle for independence and in the post-independence era remain a subject of contention even in today's politics in the DRC (United Nations, 2015).

The adoption of political pluralism and the holding of democratic elections, in particular, the 2006 elections brought fresh air into the institutional process and revived hopes for the legitimacy of state institutions and the central government. However, political liberalization needs to be further consolidated, especially in the areas of transparency and equitable representa-tion of all regions and segments of the population (United Nations, 2015).

The global environment remains a factor in the country's prospects for conflict resolution and long-run economic growth and development. In the post-cold war era, although strategic imperatives have changed, the DRC remains strategically significant in the global fight against terrorism. It is also the epicentre of the scramble for natural resources driven by the ever-rising demand for energy and industrial raw material. In this con-text, the stability and consolidation of the state's control over the territory have critical role dimensions. Hence the urgency for concerted efforts at regional and international levels to support the Congolese government and people to find solutions to the conflicts and move to a path of strong sustained and shared economic growth (United Nations, 2015). Why the European Union, USA interfere in DRC. According to the Fund for Peace (2019) annual report, DRC is the fifth with 110.2 score which indicates the high level of failure in the list.

\subsection{Somalia as Collapsed State}

Before the colonial partition of Somali territories, there was no permanent centralized authority but a variety of local administrations and occasional centralized rules (Khayre, 2017). In 1956 Italian Somalia land and 1960 British Somalia land conducted the first democratic election where the Somali Youth League (SYL) and the Somali National League (SNL) won the overwhelming majority of seats in the assembly of each unit respectively. After the independence and unification of two Somalia lands, Somalia enjoyed nine years of parliamentary democracy, arguably producing the first peaceful, democratic transfer of power in Africa (Khayre, 2017). The first Somali constitution of 1960, functional till 1969, safeguarded most of the human rights enshrined in the United Nations Declaration of Human Rights and provided multiparty election. Furthermore, there was a functioning independent judiciary and a unitary state structure. Additionally, political violence was non-existent during civilian rule.

However, the civilian rule was dominated by rampant corruption, nepotism, and embezzlement in the later years of the civilian government. Furthermore, post-independence civilian governments were inefficient and incapable of creating a comprehensive national political culture (Rotberg, 2004). The military overthrew the civilian government by assassinating the elected civilian president in a bloodless coup in 1969. But the junta did not wait long to repeat these social and political evils upon Somalis. Backed by foreign intervention, Siad Barre destroyed institutions of government and democracy, abused human rights, committed corruption in terms of favouritism and embezzlement for himself and his sub-clan where all of the major clans and sub-clans became alienated (Rotberg, 2004). Instead of winning the battle of ideas, the military tried to use might where populism shifted to militarism and politicization and militarization of clan politics (Khayre, 2017), and the military regime was removed from power in 1991 via a coup.

Since 1991, Somalia has been the only United Nations member country without an effective governmentcollapsed state. Consequently, civil war, terrorism, lawlessness, and piracy plague the country that is in perpetual turmoil (Khayre, 2017). Since then, because of the colonial legacies of dived and rule policies, hostile clan politics, and other external impacts, Somalia is a stateless society. According to the Fund for Peace (2019) annual report, Somalia is the second with a 112.3 score, just the second next to Yemen in the top list of state collapse.

Somalia not only represents the most protracted case of state collapse but also has witnessed the emergence of multiple local governance systems, both formal and informal, which rarely acknowledged in the state failure debate. Furthermore, the de facto existence of a 'greater Somalia based on a shared cultural identity, religion, cross-border kinship relations, and regional trade, transport, and finance networks, allows drawing comparisons between comparable sub-national political orders within Somalia (Hagmann, and Markus, 2009). In contrast to state collapse, Somalia demonstrates that a population can survive by creating informal systems of adaptation, 
security, and governance in response to the prolonged absence of a central government' (Hagmann, and Markus, 2009).

The clan is the building blocks of security, party formation, office appointments, governance systems, and power-sharing modalities in Somalia. A multitude of clan-based "warlords" and Somalia's leadership deficit as negative factors for the rebuilding process. Furthermore, a wide range of domestic actors who profited from continued state collapse and conferences work against efforts of state-building are pitfalls for it. Moreover, the prioritization of clan legitimacy and loyalty over state legitimacy and widespread public mistrust of the central government are also challenges for the state rebuilding process (Khayre, 2017). Despite many conferences were organized with the help and assistance of neighboring countries, regional organizations, and the United Nations; warlords, and clan leaders are reluctant to reach an agreement (Khayre, 2017).

During the Cold War, superpowers continuously courted Somalia to come into, or stay within, their sphere of influence due to its strategic geographic location. However, after the fall of the Berlin Wall, its importance diminished, and the superpowers abandoned it to its device (Richburg, 1992). Because of the end of the Cold War and the outbreak of the first Gulf War, no significant external mediation efforts made to address Somalia's deepening crisis. In fact, for the last 24 years, more than sixteen peace and reconciliation conferences have been held, but none have been successful (Khayre, 2017).

The United Nations interfere in Somalia to ameliorate the situation by urging warring parties to create a conducive environment for the delivery of humanitarian relief supplies. Furthermore, in January 1992 the United Nations Security Council (UNSC) adopted resolution 733 to establish the first UN peacekeeping operation in Somalia (UNOSOM I) with a mandate to maintain a ceasefire, promote reconciliation, and a political settlement, and provide urgent humanitarian assistance. With this apparent diplomatic breakthrough, the UNSC endorsed a new Resolution (814) to expand the UN's role in Somalia, deploying some 28,000 peacekeepers and giving UNOSOM II a mandate to restore peace, law, and order and help re-establish a national government.

However, lack of transparency and impartiality, disagreement on the selection of participants, and mistrust affect the mission negatively. A perceived bias of the United Nations and the United States antagonized clan warlords, and disputes soon emerged over the different interpretations of agreements reached. Military and diplomatic interventions of both the USA and UNOSOM withdrew and failed to achieve reconciliation and revive state collapse in Somalia.

In 2000 the Djibouti government hosted the Somalia National Peace Conference in the town of Arta. The 'Arta process achieved an important political breakthrough by producing a power-sharing agreement, bottom-up approach, and established a Transitional National Government (TNG) with its charter. In the conference, except representatives from Somalia land and Put land, various clan elders, civic leaders, business people, and international community representatives were participating and adopted a unitary, rather than federal, state in Somalia(Malito, 2011). It also endorsed Somali state-building on a 4.5 power-sharing formula, where four big clans get an equal share of the members of parliament, and any representation and a coalition of all other 'minority clans' is considered to be half a clan and get their share accordingly.

TNG was supported by Egypt, Libya, Eritrea, the Gulf States, and the UN but failed to win the backing of Somalia's land, Put-land, and neighboring states (Malito, 2011). As a counter in 2001, those opposed to this plan formed a coalition against the TNG called the Somalia Reconciliation and Restoration Council (SRRC), supported by Ethiopia and United States (Malito, 2011). This further highlighted how the interests of regional powers had become a hindrance to reconciliation in Somalia.

This led to in 2004, IGAD organized a conference to bring the Djibouti-backed TNG and its Ethiopianbacked opponents the SRRC into a comprehensive political settlement held in Kenya- Mbgathi Peace Conference. It resulted in the adoption of the Transitional Federal Charter and a Transitional Federal Parliament and concluded by electing a president in October 2004 for a five-year transitional period. In direct opposition to the Arta process of 2000 unitary state structure, the 2004 Mbgathi process proposed a federal state structure. Since 2000, diplomatic antagonism during peace talks has undermined Somalia's reconciliation process (Malito, 2011). Alternative diplomatic initiatives, based on rival state-building approaches, were attempting to orient Somalia's reconstruction on different policy trajectories: Ethiopia and Western actors encouraged a decentralized approach while competing for Arab initiatives (sponsored by Egypt, Eritrea, and the Arab League) supported a centralized approach (Malito, 2011).

Most external actors have approached the Somali crisis from the perspective of their national security and strategic interests (Malito, 2011; Hagmann, and Markus, 2009). Any intervening foreign power, therefore, brings with its national interests and political value system and could limit the success. Furthermore, external interventions have been uncommitted, partisan, uncoordinated, misinformed, and incompetent in their mediation efforts (Khayre, 2017).

The only successful responses to this problem of sovereignty have emerged from local projects of subnational state-building. For instance, the self-proclamation of the independent Republic of Somaliland in 1991, and the declaration of Punt-land as an autonomous region in 1998 are manifestations of sub-national state- 
building projects in Somalia. In the end, the domestic actors are unable to get a solution for their burden, and similarly, the multilateral military and humanitarian interventions led by different actors failed to restore peace and stability at best or exacerbated the situation at worst mainly because of their intrinsic top-down nature, realist and capacity oriented approaches (Malito, 2011). The failure of a decade of reconciliation and statebuilding efforts in Somalia is an interest-driven crisis (Menkhaus, 2003).

\section{Lesson from the Three Comparative Analysis}

The selected cases (Burundi, the DRC, and Somalia) are characterized by insurgencies, anarchy, warlords' competitions, instabilities, underdevelopment, and external interventions in the form of imperialism and neocolonialism. Africans have been challenged by historic and economic factors, more than states on other continents. This has been exacerbated by imperialism and 'neo-colonialism'. Hence, there is no denying that external actors like governments, international organizations, and transnational companies have played a major part in Africa's current situations (Thomson, 2010).

The conflicts in the DRC, Burundi, and Somalia have been costly in various ways for the neighboring countries, the sub-region, and the continent as a whole. The wars have prevented them and their neighbors from taking advantage of cross-border trade opportunities. They have compromised regional infrastructure development, especially in the power and transport sector, thus undermining growth and regional integration. The wars have also corroded the envi-ronment for cooperation in the region that retard the implementation of mutually beneficial regional integration programs.

\section{Concluding Remarks}

Failing, Failed, and collapsed states are among the debates in the academic circles and living realities characterized by economic breakdown, insecurity, and unfit government to effectively control their territory and comply with their international obligations and resulted in problems without passports. Why should we focus on these states? There are two reasons. First, as failed states have accumulated and persisted, they have generated or intensified a significant part of the global governance, security, peace operation, and humanitarian problems that is the international communities' core mission to confront. In this regard, failed states have adverse negative effects on themselves and their people in terms of economic breakdown, insecurity, and unfit government and have impacts on neighbors, region, and global levels in terms of security, peace, and governance challenges. Second, rebuilding a failed state and preventing sates from failure through both curative and preventive interventions is a moral and legal responsibility of the global governance institutions to protect from these ills. Hence, such countries must be brought into the mainstream agenda of global governance, peace, and security for humanity seek.

The above cases showed that state capacity and functionality problems in Africa are the results of both internal and external factors. Among the external interventions is colonial administration that left with weak institutions, artificial boundary, authoritarian rule, the balkanization of groups, and eroding state sovereignty and legitimacy. The other external factor was the cold war military, ideological, and strategic rivalry where Africa was a battlefield. The structural adjustment program of the Bretton Wood Institutions has also hurt the viability of African states by forcing them to downsize their capacity in the name of privatization and a free market economy. Presently the securitization of failed states by the big boys may also undermine the capacity and independence of African states to do their day to day business.

Though the external interventions have a far significant impact on the African state's capacity and functionality, domestic factors also have a contribution to the wide prevalence of state fragility, failure, and collapse in Africa. Most significantly neo-patrimonial, authoritarian, and corrupt rulers take the lion share of the problem. Furthermore, parochial political culture, a weak economy, weak civil societies, socio-political fragmentation, and poor education have contributed to the ills of the continent.

Finding solutions to the existential problems of the selected cases requires addressing the root causes of the problem not only to bring an end to existing functionality problems but also to prevent new cycles of fragility. The focus should be on building strong public institutions and designing and implementing a peace building agenda, rebuilding the economy, reforming the security sector, strengthening regional integration, and take positive lessons from external interventions.

Having a functional and strong state is imperative for the realization of development, peace, law, and order, and the prevention of further violence at national, sub-regional, and continental levels. Addressing the gap on where to focus is critical: what is there or what ought to be there. The gap between external rhetoric and empirical realities is widening that demands critically rethinking approaches to peace and state-building. There is a contradiction between the state-building mechanisms of the west and the power elites of Africa. The elites were concerned with regime survival, while the west for the survival of their national interests(Moe, 2010).

Addressing the path gap is also critical. External actors engaged in peace, security, and governance and state-building need to pay greater attention to actual conditions for institutionalizing sustainable political and 
social order. An increasing focus on harmonizing state-society relations that includes non-state actors and institutions which are currently left outside the rebuilding narratives has to be invited in these processes. Rebuilding state institutions can only be successful if it is supported by the populations of the territory who have a deep interest in their formation, strengthening, and perpetuation (Khayre, 2017). Moreover, the best way to ensure people's faith in the state and its institutions is to base the institutions on human security, harmonization, and rule of law. Unless and until state-building takes root in the indigenous society and with committed local leadership, no amount of external support will make it fix (Usman and Hany, 2007).

The solutions for state failures have to be a multilayer. Since the end of the cold war, a variety of international responses have been attempted and proposed by the international community to address problems. Among the trials, intervention in the name of humanitarian, neo-liberalism, securitization, state-building, and peacekeeping operations are the main ones. The ongoing nature of the phenomenon of state failure and security threats for the 21 st century demanded to focus on state-building, the creation of new government institutions, and the strengthening of existing ones, by the world community (Fukuyama, 2005).

Making securitization efforts altruistic is critical. The securitization of failed states in political and academic discourse, and the attention given to these situations in policy circles, also reflects a subjective construction of international security threats. Less positively, the securitization of weak and failed states reinforces a tendency to externalize problems in the developing countries, and even to demonize the 'other' as a pretext for control and intervention (Newman, 2009). Furthermore, instead of prioritizing the securitization of the west security interest alone, it is better to see it from the potentials and interests of these states as well.

The researcher believes that if humanitarian intervention, peace operations, securitization, and liberal peace are done from the goodwill of deontology, the problems and challenges of fragile, failed, and collapsed sates will be addressed. Consequently, this in turn will bring positive spill over impacts for all stakeholders.

\section{References}

Jean-Germaine, G. (1996) "Towards a Taxonomy of Failed States in the New World Order: Decaying Somalia, Liberia, Rwanda and Haiti”, Third World Quarterly, Vol.17(3), pp. 455 - 471.

Zartman, W. (1996) "Introduction: Posing the Problem of State Collapse" in Collapsed States: The Disintegration and Restoration of Legitimate Authority, London, Lynne Rienner, pp. 1 - 11.(ERT-scans)

Tusalem, Rollin F. (2016) "The Colonial Foundations of State Fragility and Failure”, Polity, Vol. 48(4), pp.445495.

Cem, Karadeli (2009). "Failed State Concept and the Sub-Saharan African Experience" in Journal of Arts and Sciences Say1: 12 / Aralık 2009

Eriksen, Stein S. (2011). 'State Failure' in Theory and Practice: The Idea of the State and the Contradictions of State Formation` Review of International Studies 37(1), 229-247

Acemoglu Daron \& Robinson. A. James. (2012). Why Nations Fail: The Origins of Power, Prosperity and Poverty. Profile Books. London,

Fukuyama, Francis(2005). State-building: Governance and World Order in the Twenty-First Century. Profile Books. London,

Ghani, Ashraf \& Lockhardt, Clare(2008). Fixing Failed States: A Framework for Rebuilding a Fractured World. Oxford University Press. New York,

Rotberg, R. (2003). State failure and state weakness in a time of terror. Cambridge, MA: World Peace foundation; Washington, D.C.: Brookings Institution Press.

Rotberg, I. Robert (ed)2004). When States Fail: Causes and Consequences. Princeton University Press. New Jersey

Usman, Hannan and Hany Besada(2007). "Dimensions of State Fragility: A Review of the Social Science Literature" CIGI WORKING PAPER no.3 State Fragility

Yumlu,Seda(2012). Approaches to the Root Causes of State Failure and Collapse. MA thesis

E. Akani, Christian (2016). "A Critical Analysis of the Debate on State Failure in Africa" Global Journal of HUMAN-SOCIAL SCIENCE:Political Science, V 16 (4) ,pp 36-46.

Baker, Pauline H. (2007) "Fixing Failing States: The New Security Agenda" The Whitehead Journal of Diplomacy and International Relations, pp: 85-96

Cojanu, Valentin and A. I. Popescu (2007). "Analysis of Failed States: Some Problems of Definition and Measurement” The Romanian Economic Journal ,Year X,No,25, PP: 113-132

Townshend, Ashley (2007). Anatomy of State Failure: Case Studies in Zaïre, Afghanista and Yugoslavia

Tainter, J. A. (1990). The collapse of complex societies. Cambridge, UK: Cambridge University Press.

Nkurunziza ,Janvier D. (2018). The origin and persistence of state fragility in Burundi. Commission on State Fragility, Growth and Development

The Fund for Peace (2019) Fragile States Index Annual Report 2019. Retrieved 30 June 2019

Ashraf Ghani and Clare Lockhart(2008).FIXING FAILED STATES:A Framework for Rebuilding a Fractured 
World. Oxford University Press: Oxford.

Khayre, Ahmed A. (2017). "Somalia: An Overview of the Historical and Current Situation" Working Paper in SSRN Electronic Journal

Malito,Debora V.(2011). Somalia and state-building: state capacity or state autonomy? A Critical review of how to decolonize African studies. Retrieved on July 2019.

Heilbrunn, John R. (2006). "Paying the Price of Failure: Reconstructing Failed and Collapsed States in Africa and Central Asia" in Perspectives on Politics,Vol. 4(1), pp. 135-150

Lambach, Daniel eta 1 (2015). "The Causes of State Collapse: Results from an Analysis Using Multi-Value QCA.” COMPASSS Working Paper 80 Available at http://www.compasss.org/wpseries/ LambachJohaisBayer2015.pdf

Moe, Louise W. (2010). Addressing state fragility in Africa: A need to challenge the established 'wisdom'? FIIA REPORT 201022

Bates, Robert H. (2005). Political Insecurity and State Failure in Contemporary Africa. Working Papers

Thürer, D. (1999). The failed state' and international law. International Review of the Red Cross, 836, 731-761.

Hentz, James J.(2004). "State Collapse and Regional Contagion in Sub-Sahara Africa: Lessons for Zimbabwe" South African Journal of Military Studies, Vol. 32(1), pp:143-156.

Ncube, Mthuli and Basil Jones(2013). "Drivers and Dynamics of Fragility in Africa" in Chief Economist Complex AEB Volume 4, Issue 5

Newman ,Edward (2009). "Failed States and International Order: Constructing a Post Westphalian World" Contemporary Security Policy, Vol.30(3), pp.421-443

Brooks, Rosa E.(2005). "Failed States or the State as Failure?" In the University of Chicago Law Review, Vol.72 (4).

Iqbal ,Zaryab and Harvey Starr(2008). Bad Neighbors: Failed States and Their Consequences Conflict Management and Peace Science, Vol.25: pp315-331

Yoo, John (2011). "Fixing Failed States" in California Law Review Vol. 99(Issue 1) Art. 3, pp: 95-150.

Hagmann, Tobias and Markus V. H. (2009) "Failures of the State Failure Debate: Evidence from the Somali Territories" in Journal of International Development, Vol. 21, Pp: 42-57

Orman, Turkan F.(2016). An Analysis of the Notion of a "Failed State" In International Journal of Social Science Studies Vol. 4(2), pp: 77-85.

Olowu, Dele and Paulos Chanie(eds.) (2016). State Fragility and State Building in Africa: Cases from Eastern and Southern Africa. New York: Springer International Publishing

Menkhaus, Ken (2003) "State Collapse in Somalia: Second Thoughts" Review of African Political Economy Vol.30 (97), pp: 405-422

Wilén, Nina \& Paul D. Williams( 2018) "The African Union and coercive diplomacy: The case of Burundi" the journal of modern African studies, Vol. 56. Issue 4, pp: 673-696.

Solomon, Hussein and Cornelia Cone(2004) "The State and Conflict in the Democratic Republic of the Congo" South African Journal of Military Studies, Vol 32(1), Pp:51-75.

United Nations (2015) Conflicts in the Democratic Republic of Congo: Causes, impact and implications for the Great Lakes region. United Nations Economic Commission for Africa: Addis Ababa.

Thomson, Alex (2010). An Introduction to African Politics, $3^{\text {rd }}$ ed.. London: Routledge.

Embiale Beyene is an assistant professor of political science and international relations at the Department of Political Science and International Studies, Bahir Dar University, Ethiopia. H e has bachelor degree in political science and international relations and master degree in International Relations, both from Addis Ababa University, Ethiopia. His research areas and interests are in transboundary water governance; hydro-politics of the Nile; global governance, peace and security; foreign policy and diplomacy. 